Jurnal Teknik Komputer AMIK BSI

Volume 7, No.2, Juli 2021

P-ISSN 2442-2436, E-ISSN: 2550-0120

Akreditasi Ristekdikti, No: 36/E/KPT/2019 (Sinta 4)

DOI: $10.31294 /$ jtk.v4i2

\title{
Comparison AHP-MABAC And Waspas Methods For Supplier Recommendations
}

\author{
Wina Yusnaeni ${ }^{1}$, Marlina ${ }^{2}$, Ratih Yulia Hayuningtyas ${ }^{3}$, Retno Sari $^{4}$ \\ ${ }^{1,2}$ universitas Bina Sarana Informatika \\ ee-mail: wina.wyi@bsi.ac.id \\ 2e-mail: marlina.mln@bsi.ac.id \\ ${ }^{3,4}$ Universitas Nusa Mandiri \\ 3e-mail: ratih.ryl@nusamandiri.ac.id \\ 4e-mail: retno.rnr@nusamandiri.ac.id

\begin{tabular}{ccc}
\hline Diterima & Direvisi & Disetujui \\
$23-04-2021$ & $14-06-2021$ & $17-06-2021$ \\
\hline
\end{tabular}

\begin{abstract}
Abstrak - Kebutuhan pengadaan barang atau jasa yang berkualitas suatu perusahaan ditentukan oleh supplier yang baik. Berdasarkan hal tersebut, sebaiknya perusahaan melakukan pemilihan serta evaluasi terhadap supplier yang telah bekerjasama berdasarkan kriteria yang telah ditentukan. Tujuannya agar supplier yang bekerjasama bisa bersaing secara sehat dalam meningkatkan kualitas dan konsistensinya sebagai pemasok terhadap perusahaan. proses penentuan rekomendasi supplier menggunakan metode Sistem pendukung keputusan multikriteria yang bisa membatu dalam konsistensi kriteria serta keputusan yang diambil lebih akurat. Pengolahan kriteria menggunakan metode AHP untuk melihat konsistensi bobot antara kriteria. Sedangkan perbandingan metode MABAC dan WASPAS digunakan sebagai pembanding dengan data aktual untuk mengetahui metode yang sesuai dengan studi kasus ini. Dari hasil penelitian perbandingan data aktual dengan metode MABAC memiliki kesamaan hasil dari supplier yang direkomendasikan dibandingkan dengan metode WASPAS.
\end{abstract}

Kata Kunci: Sistem pendukung keputusan multikriteria, Alternative, Metode AHP

Abstract - The procurement of the goods or services of a company is determined by qualied suppliers. Therefore, it is necessary for a company to choose and evaluate the suppliers that have cooperated based on the required criteria. The purpose is that all of the suppliers can compete in improving the quality and their consistency as a supplier to the company. The process to decide the appropriate supplier in this study is multicriteria support decision methods that can help in the consistency's criteria and the accuracy of the decision. Here we perform the calculation criteria for consistency with the AHP method that will further calculate the weight of criteria and alternatives against the criteria using the method of MABAC and WASPAS. The results of the data comparison using the method of MABAC have actual results with the suppliers recommended and not recommended compared to the method of WASPAS.

Keywords: multicriteria support decision, alternative, AHP method

\section{PENDAHULUAN}

With the need to supply goods or services, a company needs a supplier or supplier that can help meet the needs of complementary production activities. Determination of suppliers that needed by the company must go through the strict selection and always carried out a periodical evaluation of the supplier so that the quality of the goods or services will be maintained. The selection of the right Supplier is a very important decision with wide implications in the supply chain (UmaDevi et al.,
2012). The competitiveness that occurs in a company depends on the level of activity that occurs in an organization, therefore the importance of improving the results of companies such as the selection of a competent supplier can improve the performance of a company. In providing the recommendations of the competent supplier required analysis with multi-criteria and evaluation, assessment is supported by methods that can provide the alternative decision more efficiently. The wrong choice of a supplier or source can disturb the company's financial and operational position, 
especially to the upstream company (UmaDevi et al., 2012).

Beside that, determining the supplier and its consistency are not only based on one criteria, but it takes several criteria. This is done so that the supplier can maintain consistency in the provision of goods or services to the company. The selection of a supplier or source could interrupt the financial position and operations of the company in the echelon upstream the supply chain, supplier selection continues to be an Element key in the process of buying industry, and it seems to be one of the main activities of professionals in the industry supplier and is considered as intangible asset of any organization (UmaDevi et al., 2012).

The selection process has a significant role in reducing costs, increasing profits and product quality, and companies often make mistakes in selecting the supplier as a single decision problem, only the cost factor when making a decision (Taherdoost \& Brard, 2019). The development of the decision support system currently being one of the alternatives to help in decision making by using the method - a method of SPK. one of them is a Methods WASPAS is working on making decisions effectively with complex problems with how to simplify and make the decision process faster by solving the problem into its parts (Tundo \& Kurniawan, 2019), AHP Method (Analytical Hierarchy Process is a method with the theory of measurement with the determination of the priority of some criteria by performing a pairwise comparison of each criterion (Haldar et al., 2012).

MABAC Method (Multi Attributive Border Approximation Area Comparison) provides stable solution (consistent) and this is considered as a reliable method for rational decisions(Božanić et al., 2016). Methods MABAC is considered as a method that has a consistency that can be relied upon in making rational decisions, compared with other methods of decision making with multicriteria (SAW, COPRAS, MOORA, and VIKOR)(Bozanic et al., 2016). In previous research, many methods used in the determination of such a decision by using the vikor method, Topsis, PROMETHEE method, the GRA method, EDAS model and the TODIM model that has been widely studied by researchers (Wang et al., 2019). Based on the previous literatures, the advantages of the MABAC method calculate the distance between the alternative and the bored approximation area (BAA), and consider the uncertainty of the decision and uncertainty of the environment decision, so we will get more accurate decisions and effective results(Wang et al., 2019). In this research, the authors try to make a comparison of criteria using the AHP method to measure the consistency of the criteria, and comparison of the method with the method of MABAC and methods WASPAS in data processing. the results of the research is a comparison of the methods mabac and waspas, which method is more precise and accurate with the actual data in the determination of the recommendations of the supplier.

\section{METODOLOGI PENELITIAN AHP}

Determining the criteria for an alternative assessment is one of the most important things about decision making. Criteria affect the result and the criteria weight coefficient (UmaDevi et al., 2012). Where the analysis can be used in the criterion weight coefficient is to use the AHP method. with the stages,

a) Steps 1: to measure consistency criteria, Making Matric comparative level of importance of criteria and counts the every column,

b) Step 2: Divide each value of the matrix by the total number of each column to get the normalized matrix,

c) Step 3: Sum the row and divide then by the number of elements to get the priority value of each criteria, Step 4: To measure consistency by scaling each value of the first column with a priority value,

d) Step 5: Total summation of rows divided by relative priority elements $(\Lambda \max )$,

e) Step 6: Calculation Index Consistency (CI), Step 7: Calculation Consistency Ratio (CR).

MABAC (Multi Attributive Border Approximation Area Comparison)

The stages in the Method MABAC (Muravev \& Mijic, 2020):

a) First Step : Make initials matrix decision (X) evaluate alternative $m$ to $n$ criteria.

b) Second Step: Normalization of Matrix $\mathrm{X}$ elements.

c) Third Step: Weighted matrix calculation (V)

d) Fourth Step: Determination of regional boundaries of the approximate matrix $(G)$ (Xue-Guo et al., 2019).

e) After calculation of $g_{i}$ value of the criteria formed border area of the estimate. In the form of $\mathrm{n} \times 1$ where $\mathrm{n}$ is the number of criteria displayed from the alternative offered.

f) Fifth Step: Calculation of an alternate distance matrix element from the approximate border area. Alternate distance from the approximate border area $\mathrm{q}_{\mathrm{ij}}$ specified as a difference in the weighted matrix element (V) and the approximate regional border value $(\mathrm{G})$. and

g) Sixth Step : of ranking the values of the criterion function against the alternative.

WASPAS (Weights Aggregated Sum Product Assessment) 
The approach of WSM to calculate the total score of an Alternative as a large number of criteria, While the Approach of WPM made to prevent the alternative which has the value of the attribute or criteria bad (Bid \& Siddique, 2019) (Chakraborty, Bhattacharyya, et al., 2015). In optimization criteria are searched based on the optimization of two criteria. Optimization of the first criteria is to have similarities in the weight of the criteria with the WPM method. MCDM's approach is popular and can be well received in evaluating alternative numbers as criteria determination. The stages in the calculation method WASPAS: The normalized value of the matrix with the criteria of benefit or cost, to Calculate the Preference (Qi) (Chakraborty, Zavadskas, et al., 2015).

\section{Supplier Selection}

In the determination of the supplier, there are three steps : that first identify the criteria, the most common is about quality, performance, delivery, cost, ability but the price is no longer a major factor. Because in fact, the selection of adequate criteria depends on the purchase. Secondly, surveys use the questionnaire used as a result analysis and the determination of the criteria weights. The third step makes Multicriteria decisions using methods to generate supplier recommendations (Taherdoost \& Brard, 2019).

Data Collection

Table 1. Criteria

\begin{tabular}{lcl}
\hline \multicolumn{1}{c}{ Criteria } & Weight & Description \\
\hline Price (subkon Fee) & 1 & Expensive \\
\cline { 2 - 3 } & 2 & Moderate \\
\cline { 2 - 3 } & 3 & Cheap \\
\hline $\begin{array}{l}\text { Quality of goods/work } \\
\text { results }\end{array}$ & 1 & Not Good \\
\cline { 2 - 3 } & 2 & Enough \\
\hline Punctual delivery of \\
goods/job execution & 3 & Good \\
\cline { 2 - 3 } & 1 & Not Good \\
\hline Payment method & 2 & Enough \\
\hline Good service/Tngkah & 3 & Good \\
\cline { 2 - 3 } Laku & 2 & Cash \\
\hline K3L Aspect & 1 & Credit \\
\cline { 2 - 3 } & 2 & Not Good \\
\cline { 2 - 3 } & 3 & Goderate \\
\hline Sum & 2 & Not Good \\
\hline
\end{tabular}

Sumber : (Yusnaeni et al., 2021)

Processed data amounting to 43 suppliers which are made as many as eight data included in the recommended and not recommended. An assessment conducted by decision-makers such as directors, managers, and supervisors. To the flow of research begins with the collection of the required data, namely the criteria and alternative which will then be processed using the method of MABAC and
WASPAS. for more details flow diagram of the study is depicted in figure 1 below:

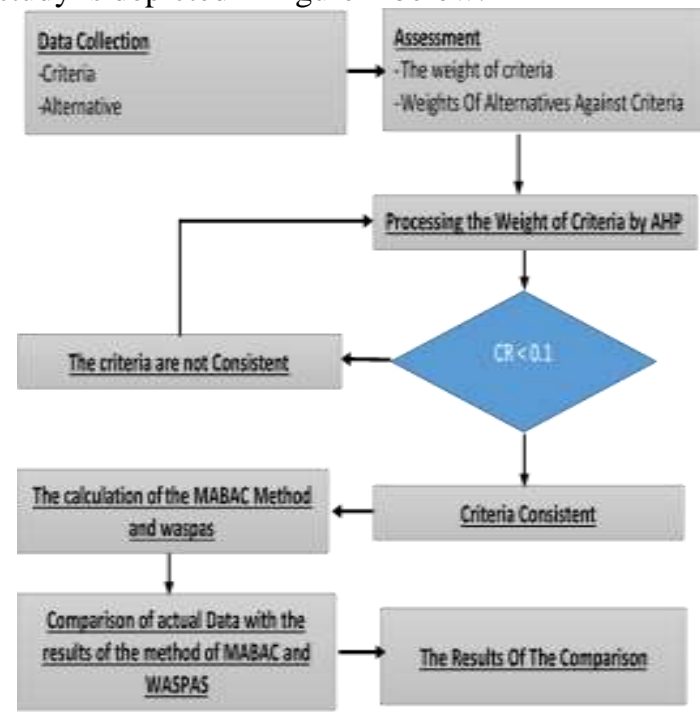

Sumber :(Yusnaeni et al., 2021)

Gambar 1. Research Diagram

HASIL DAN PEMBAHASAN

Completion of recommendations on the supplier starts by processing the data by the calculation of MABAC and WASPAS methods, including defining criteria, weights, and alternatives until the rating of calculation results.

The definition of consistency criteria with ahp

The calculation of the consistency of the criteria with an AHP Method to make a matrix of normalized and perform the calculation of the consistency:

Table 2. The Matrix consistency of each criteria

\begin{tabular}{cccccccc}
\hline & & & & & & & Sum \\
\hline & 0,043 & 0,044 & 0,036 & 0,028 & 0,045 & 0,079 & 0,278 \\
804 & 428 & 518 & 763 & 484 & 929 & 927 \\
\cline { 2 - 8 } & 0,131 & 0,133 & 0,328 & 0,172 & 0,075 & 0,079 & 0,921 \\
& 413 & 284 & 658 & 58 & 807 & 929 & 671 \\
\hline 0,131 & 0,044 & 0,109 & 0,258 & 0,075 & 0,079 & 0,7 \\
413 & 428 & 553 & 869 & 807 & 929 & \\
\hline 0,131 & 0,066 & 0,036 & 0,086 & 0,075 & 0,133 & 0,529 \\
413 & 642 & 518 & 29 & 807 & 216 & 886 \\
\hline 0,219 & 0,399 & 0,328 & 0,258 & 0,227 & 0,133 & 1,567 \\
022 & 851 & 658 & 869 & 422 & 216 & 038 \\
\hline 0,219 & 0,666 & 0,547 & 0,258 & 0,682 & 0,399 & 2,773 \\
022 & 419 & 763 & 869 & 267 & 647 & 987 \\
\hline
\end{tabular}

Sumber:(Yusnaeni et al., 2021)

$\Lambda=6,60743$, $\mathrm{CI}=0,121486$, Comparison value between criteria is consistent. $\mathrm{CR}=0,097972539$ Nilai $C R<0.1$. the results of the $C R$ show the coefficients of the criteria are consistent and can be used.

\section{Calculation with MABAC Method}

First Step until Third Step: Create a matrix of the initials of the alternative assessment decisions against the criteria, the Normalization of the elements of the matrix X. Calculate the value weights (V). 
Table 3. Matrik decision (X)

\begin{tabular}{ccccccc}
\hline Supplier & K1 & K2 & K3 & K4 & K5 & K6 \\
\hline $\mathbf{2}$ & 1 & 2 & 3 & 2 & 2 & 2 \\
\hline $\mathbf{5}$ & 2 & 1 & 2 & 1 & 2 & 1 \\
\hline $\mathbf{8}$ & 3 & 3 & 3 & 2 & 3 & 3 \\
\hline $\mathbf{1 3}$ & 1 & 3 & 3 & 2 & 3 & 3 \\
\hline $\mathbf{2 1}$ & 2 & 3 & 3 & 2 & 3 & 3 \\
\hline $\mathbf{3 0}$ & 2 & 1 & 2 & 1 & 2 & 1 \\
\hline $\mathbf{3 8}$ & 2 & 3 & 3 & 2 & 3 & 3 \\
\hline $\mathbf{4 0}$ & 2 & 2 & 1 & 1 & 1 & 2 \\
\hline Max & 3 & 3 & 3 & 2 & 3 & 3 \\
\hline Min & 1 & 1 & 1 & 1 & 1 & 1
\end{tabular}

Sumber :(Yusnaeni et al., 2021)

Table 4. Matrik Weight (V)

\begin{tabular}{rrrrrr}
\hline \multicolumn{1}{c}{$\mathbf{l}$} & & & \\
\hline $\mathbf{K 1}$ & $\mathbf{K 2}$ & $\mathbf{K 3}$ & $\mathbf{K 4}$ & $\mathbf{K 5}$ & $\mathbf{K 6}$ \\
\hline $\mathbf{0 , 0 8 7 6 0}$ & 0,19992 & 0,21910 & 0,12943 & 0,34113 & 0,59947 \\
$\mathbf{9}$ & 6 & 5 & 5 & 3 & 1 \\
\hline $\mathbf{0 , 0 6 5 7 0}$ & 0,13328 & 0,16432 & 0,08629 & 0,34113 & 0,39964 \\
$\mathbf{7}$ & $\mathbf{4}$ & 9 & & 3 & 7 \\
\hline $\mathbf{0 , 0 4 3 8 0}$ & 0,26656 & 0,21910 & 0,12943 & 0,45484 & 0,79929 \\
$\mathbf{4}$ & 8 & 5 & 5 & 5 & 4 \\
\hline $\mathbf{0 , 0 8 7 6 0}$ & 0,26656 & 0,21910 & 0,12943 & 0,45484 & 0,79929 \\
$\mathbf{9}$ & 8 & 5 & 5 & 5 & 4 \\
\hline $\mathbf{0 , 0 6 5 7 0}$ & 0,26656 & 0,21910 & 0,12943 & 0,45484 & 0,79929 \\
$\mathbf{7}$ & 8 & 5 & 5 & 5 & 4 \\
\hline $\mathbf{0 , 0 6 5 7 0}$ & 0,13328 & 0,16432 & 0,08629 & 0,34113 & 0,39964 \\
$\mathbf{7}$ & 4 & 9 & & 3 & 7 \\
\hline $\mathbf{0 , 0 6 5 7 0}$ & 0,26656 & 0,21910 & 0,12943 & 0,45484 & 0,79929 \\
$\mathbf{7}$ & 8 & 5 & 5 & 5 & 4 \\
\hline $\mathbf{0 , 0 6 5 7 0}$ & 0,19992 & 0,10955 & 0,08629 & 0,22742 & 0,59947 \\
$\mathbf{7}$ & 6 & 3 & & 2 & 1 \\
\hline
\end{tabular}

Sumber :(Yusnaeni et al., 2021)

Table 3 and 4: the results of the normalization matrix and the value of the weight. Fourth Step, do the calculation to find the value of Determining the boundaries of the area forecast matrix $(\mathrm{G})$ with The value of $\mathrm{K} 1=0,065786, \mathrm{~K} 2=0,207797$, $\mathrm{K} 3=0,179478, \quad \mathrm{~K} 4=0,105186, \quad \mathrm{~K} 5=0,376113$, K6=0,628975. Fifth Step: based on the value of $V$ and $G$ further perform the calculation of matrix elements the distance of an alternative from the area of the approximate border (Qi)..

\section{Table 5. The Value Of Weight}

\begin{tabular}{lr}
\hline Supplier & \multicolumn{1}{c}{ Count } \\
\hline $\mathbf{2}$ & 0,0133437 \\
\hline $\mathbf{3}$ & 0,0072315 \\
\hline $\mathbf{5}$ & - \\
\hline
\end{tabular}

\begin{tabular}{ll}
\hline & 0,3729452 \\
\hline $\mathbf{8}$ & 0,3497159 \\
\hline $\mathbf{1 3}$ & 0,3935203 \\
\hline $\mathbf{2 1}$ & 0,3716181 \\
\hline $\mathbf{3 0}$ & - \\
& 0,3729452 \\
\hline $\mathbf{3 8}$ & 0,3716181 \\
\hline $\mathbf{3 9}$ & - \\
& 0,0398378 \\
\hline $\mathbf{4 0}$ & - \\
& 0,2749671
\end{tabular}

Sumber :(Yusnaeni et al., 2021)

Table 5. Sixth Step: the results of the value of the order supplier recommended and the order of the bottom which is not recommended. From the above results, it is known that the ranking of the top 3 is a supplier of 13,21, and 38 get a recommendation for the selected supplier. And the position of the 3 below is the supplier, supplier 5, 30, and 40 .

\section{Calculation with WASPAS Method}

The first step in creating a matrix weights the criteria, performing the calculation of the matrix normalized based on profit or cost, the second step next, calculate the value of the preference so as to produce the ranking of the recommendations of the supplier, as in the table below:

Table 6. Normalized decision Matrix

\begin{tabular}{ccccccccl}
\hline $\begin{array}{c}\text { Suppl } \\
\text { ier }\end{array}$ & \multicolumn{9}{c}{$\mathbf{x}$} & \multicolumn{3}{c}{ Ratings } \\
\cline { 2 - 9 } & K1 & K2 & K3 & K4 & K5 & K6 & $\begin{array}{c}\text { Suppl } \\
\text { ier }\end{array}$ & \multicolumn{1}{c}{$\mathbf{Q}$} \\
\hline $\mathbf{2}$ & 1 & 0,6 & 1 & 0,6 & 0,6 & 0,6 & 2 & 0,4824 \\
& & 7 & & 7 & 7 & 7 & & 83 \\
\hline $\mathbf{5}$ & 0,5 & 0,3 & 0,6 & 0,3 & 0,6 & 0,3 & 5 & 0,5588 \\
& & 3 & 7 & 3 & 7 & 3 & & 96 \\
\hline $\mathbf{8}$ & 0,3 & 1 & 1 & 0,6 & 1 & 1 & 8 & 0,9311 \\
& 3 & & & 7 & & & & 41 \\
\hline $\mathbf{1 3}$ & 1 & 1 & 1 & 0,6 & 1 & 1 & 13 & 0,9684 \\
& & & & 7 & & & & 27 \\
\hline $\mathbf{2 1}$ & 0,5 & 1 & 1 & 0,6 & 1 & 1 & 21 & 0,9430 \\
& & & & 7 & & & & 37 \\
\hline $\mathbf{3 0}$ & 0,5 & 0,3 & 0,6 & 0,3 & 0,6 & 0,3 & 30 & 0,5588 \\
& & 3 & 7 & 3 & 7 & 3 & & 96 \\
\hline $\mathbf{3 8}$ & 0,5 & 1 & 1 & 0,6 & 1 & 1 & 38 & 0,9430 \\
& & & & 7 & & & & 37 \\
\hline $\mathbf{4 0}$ & 0,5 & 0,6 & 0,3 & 0,3 & 0,3 & 0,6 & 40 & 0,5477 \\
& & 7 & 3 & 3 & 3 & 7 & & 84 \\
\hline
\end{tabular}

Sumber:(Yusnaeni et al., 2021)

From the above results the greatest weight of the top 3 obtained by the supplier No 8,21, and 38, while the position of the bottom of the 3 suppliers, namely supplier No. 2, 30, and 40.

A comparison of the ranking Results with the actual data 3 top and 3 bottom:

Evaluation of Supplier recommendation conducted by the company from evaluation result generated actual data of recommended Suppliers keep working 
together and suppliers who are not recommended to cooperate. Based on the data that has been processed using the method MABAC and WASPAS then the resulting comparison is as follows:

Table 7. comparison actual data with MABAC and WASPAS Method

\begin{tabular}{llll}
\multicolumn{1}{c}{ Status } & $\begin{array}{c}\text { Actual } \\
\text { Data }\end{array}$ & MABAC & WASPAS \\
\hline Recommended & Supplier 8 & Supplier 8 & Supplier 8 \\
\hline Recommended & Supplier & Supplier & Supplier \\
& 21 & 21 & 21 \\
\hline Recommended & Supplier & Supplier & Supplier \\
& 38 & 38 & 38 \\
\hline Recommended & Supplier & Supplier & Supplier \\
& 22 & 22 & 22 \\
\hline Recommended & Supplier & Supplier & Supplier \\
& 23 & 23 & 23 \\
\hline Recommended & Supplier & Supplier & Supplier \\
& 34 & 34 & 34 \\
\hline Recommended & Supplier & Supplier & Supplier \\
& 20 & 20 & 20 \\
\hline Not & Supplier 5 & Supplier 5 & Supplier 2 \\
Recommended & & & \\
\hline Not & Supplier & Supplier & Supplier \\
Recommended & 30 & 30 & 30 \\
\hline Not & Supplier & Supplier & Supplier \\
Recommended & 40 & 40 & 40 \\
\hline Sumber:(Yusa
\end{tabular}

Sumber:(Yusnaeni et al., 2021)

Table 7. Based on actual data 3 suppliers arenot recommended are suppliers 5, 30, and 40 while others are recommended. From the results of calculations between the methods of MABAC and WASPAS look position 3 bottom by using the method of MABAC in accordance with the results of the position 3 on the bottom with actual data compared with the method of WASPAS.

\section{KESIMPULAN}

Research results show that The consistency of the weight between criteria using the AHP method with $\mathrm{CR} \leq 0.1$ value, By using MABAC method can be seen the number of suppliers who got the recommendation and the supplier is not recommended equally to the actual data where the supplier is not recommended in the bottom 3 is supplier 5, 30, and 40. Calculation with WASPAS method generates one differences from suppliers that are not recommended difference with actual data. Based on the comparison above MABAC method is better suited for use, in this case, study because it has the same supplier recommendations and suppliers are not recommendations with actual data compared with the method WASPAS. In the future, the Model MABAC can be expanded to improve the Method of optimizing. In addition, Research can be developed to build Applications that can be used with multicriteria more diverse, so that we can give better accuracy.

\section{REFERENSI}

Bid, S., \& Siddique, G. (2019). Human risk assessment of Panchet Dam in India using TOPSIS and WASPAS Multi-Criteria Decision-Making (MCDM) methods. Heliyon, 5(6), $\mathrm{e} 01956$. https://doi.org/10.1016/j.heliyon.2019.e01956

Božanić, D. I., Pamučar, D. S., \& Karović, S. M. (2016). Application the MABAC method in support of decision-making on the use of force in a defensive operation. Tehnika, 71(1), 129136. https://doi.org/10.5937/tehnika1601129b

Bozanic, D., Pamucar, D., \& Karovic, S. (2016). Use of the fuzzy AHP-MABAC hybrid model in ranking potential locations for preparing laying-up positions. Vojnotehnicki Glasnik, 64(3),

705-729. https://doi.org/10.5937/vojtehg64-9261

Chakraborty, S., Bhattacharyya, O., Zavadskas, E. K., \& Antucheviciene, J. (2015). Application of WASPAS method as an optimization tool in non-traditional machining processes. Information Technology and Control, 44(1), 77-88. https://doi.org/10.5755/j01.itc.44.1.7124

Chakraborty, S., Zavadskas, E. K., \& Antucheviciene, J. (2015). Applications of WASPAS method as a multi-criteria decisionmaking tool. Economic Computation and Economic Cybernetics Studies and Research, 49(1), 1-17.

Haldar, A., Banerjee, D., Ray, A., \& Ghosh, S. (2012). An integrated approach for supplier selection. Procedia Engineering, 38, 20872102.

https://doi.org/10.1016/j.proeng.2012.06.251

Muravev, D., \& Mijic, N. (2020). A Novel Integrated Provider Selection Multicriteria Model: The BWM-MABAC Model. Decision Making: Applications in Management and Engineering, 3(1), 60-78. https://doi.org/10.31181/dmame2003078m

Taherdoost, H., \& Brard, A. (2019). Analyzing the Process of Supplier Selection Criteria and Methods. Procedia Manufacturing, 32, 1024 1034. https://doi.org/10.1016/j.promfg.2019.02.317

Tundo, T., \& Kurniawan, D. (2019). Implementation of the Weighted Aggregated Sum Product Assesment Method in Determining the Best Rice for Serabi Cake Making. IJID (International Journal on Informatics for Development), $8(1), \quad 40$. https://doi.org/10.14421/ijid.2019.08107

UmaDevi, K., Elango, C., \& Rajesh, R. (2012). Vendor selection using AHP. Procedia 
Engineering, 38, 1946-1949. https://doi.org/10.1016/j.proeng.2012.06.237

Wang, J., Wei, G., Wei, C., \& Wei, Y. (2019). MABAC method for multiple attribute group decision making under q-rung orthopair fuzzy environment. Defence Technology, 16(1), 1-9. https://doi.org/10.1016/j.dt.2019.06.019

Xue-Guo, X., Shi, H., Li-Jun, Z., \& Hu-Chen, L. (2019). Green supplier evaluation and selection with an extended MABAC method under the heterogeneous information environment. Sustainability (Switzerland), 11(23). https://doi.org/10.3390/su11236616

Yusnaeni, W., Marlina, Hayuningtyas, R. Y., \& Sari, R. (2021). Laporan Akhir-Comparison AHPMABAC And Waspas Methods For Supplier Recomendations. 